\title{
COVID-19: Do DNA / RNA vaccines integrate into the genome?
}

\author{
COVID-19: As va]cinas de DNA / RNA se integram ao genoma? \\ COVID-19: ¿Se integran las vacunas de ADN / ARN en el genoma?
}

Received: 01/18/2021 | Reviewed: 01/21/2021 | Accept: 01/25/2021 | Published: 01/31/2021

\author{
Thyago José Arruda Pacheco \\ ORCID: https://orcid.org/0000-0002-8090-0644 \\ University of Brasilia, Brazil \\ E-mail: thyagojap@gmail.com \\ Victor Carlos Mello da Silva \\ ORCID: https://orcid.org/0000-0003-4129-1839 \\ University of Brasilia, Brazil \\ E-mail: victor@spctm.com \\ Danielle Galdino de Souza \\ ORCID: https://orcid.org/0000-0003-3432-0769 \\ University of Brasilia, Brazil \\ E-mail: danielle.galdino@hotmail.com \\ Maria Blandina Santos Borges \\ ORCID: https://orcid.org/0000-0003-1089-9294 \\ Medical Doctor Pediatric, Brazil \\ E-mail: mariabsborges12@gmail.com \\ Sebastião Andrade e Silva \\ ORCID: https://orcid.org/0000-0002-8483-1164 \\ Municipal Hospital of Porangatu, Brazil \\ E-mail: godiagnosticos@ hotmail.com
}

\begin{abstract}
The new coronavirus pandemic brought the need for researchers to work tirelessly in the search for therapies or vaccines that would allow control of the spread of the virus around the world. Fortunately there are two RNA vaccines against COVID-19 that have finished clinical tests and are approved in some countries. They are the first third generation vaccines approved in history and in time record. But still have some concerns about safety of DNA/RNA vaccines. Here we bring a discussion about safety of DNA/RNA: can these vaccines be integrated to the genome? In fact, DNA vaccines have an infinite chance to integrate in the cell's genome, but this infinite chance is equal zero when used with RNA-based vaccines. The vaccines based on nucleic acid (DNA and RNA) have been corresponding in advantages, becoming promising alternatives to guarantee the immunization of the new coronavirus.
\end{abstract}

Keywords: Vaccine; COVID-19; Coronavirus; RNA; DNA.

\section{Resumo}

A nova pandemia de coronavírus trouxe a necessidade de pesquisadores trabalharem incansavelmente na busca por terapias ou vacinas que permitissem controlar a disseminação do vírus pelo mundo. Felizmente, existem duas vacinas de RNA contra COVID-19 que concluíram os testes clínicos e foram aprovadas em alguns países. São as primeiras vacinas de terceira geração aprovadas na história e em registro de tempo. Mas, ainda temos algumas preocupações sobre a segurança das vacinas de DNA / RNA. Trazemos aqui uma discussão sobre a segurança do DNA / RNA: essas vacinas podem ser integradas ao genoma? Na verdade, as vacinas de DNA têm uma chance infinita de se integrar ao genoma da célula, mas essa chance infinita é igual a zero quando usadas com vacinas baseadas em RNA. As vacinas à base de ácido nucléico (DNA e RNA) têm se correspondido em vantagens, tornando-se alternativas promissoras para garantir a imunização do novo coronavírus.

Palavras-chave: Vacina; COVID-19; Coronavírus; RNA; DNA.

\section{Resumen}

La nueva pandemia de coronavirus trajo la necesidad de que los investigadores trabajaran incansablemente en la búsqueda de terapias o vacunas que permitieran controlar la propagación del virus por todo el mundo. Afortunadamente, existen dos vacunas de ARN contra COVID-19 que han finalizado las pruebas clínicas y están aprobadas en algunos países. Son las primeras vacunas de tercera generación aprobadas en la historia y en el tiempo récord. Pero, todavía tenemos algunas preocupaciones sobre la seguridad de las vacunas de ADN / ARN. Aquí traemos una discusión sobre la seguridad del ADN / ARN: ¿se pueden integrar estas vacunas al genoma? De hecho, las vacunas de ADN tienen una posibilidad infinita de integrarse en el genoma de la célula, pero esta posibilidad infinita es igual a cero cuando se usa con vacunas basadas en ARN. Las vacunas basadas en ácido nucleico (ADN y 
ARN) se han correspondido en ventajas, convirtiéndose en alternativas prometedoras para garantizar la inmunización del nuevo coronavirus.

Palabras clave: Vacuna; COVID-19; Coronavirus; ARN. ADN.

\section{Introduction}

There were three recurrences of coronavirus (sarbecovirus) in the 21st century. The first was in 2002-2003 in China with Severe Acute Respiratory Syndrome Coronavírus 1 (SARS-CoV-1), the second was in Saudi Arabia in 2012-current with Middle East Coronavirus Respiratory Syndrome (MERS-CoV) and, more recently, in China, 2019-current, the new coronavirus called Severe Acute Respiratory Syndrome Coronavírus 2 (SARS-CoV-2) has emerged, the cause of the coronavirus disease 2019 (COVID-19) which has already claimed more than 1 million fatalities (Pacheco et al., 2020a).

The new coronavirus probably came from bats and was first identified in Wuhan, China, in December 2019. SARSCoV-2 corresponds to a positive ribonucleic acid (RNA) virus, allowing the translation by host ribosomes after entering the cell. The surface structure of SARS-CoV-2 is composed of four main proteins: membrane proteins (M), protein that form the complete viral envelope (E), protein spike (S) that is used for fixation and entry into host cells through human angiotensinconverting enzyme 2 (hACE2), and in the innermost layer is found the protein of the nucleocapsid (N) encasing viral genome (Koirala et al., 2020). Compared to SARS-COV-1 they have 79,6\% of similarity, but the SARS-COV-2 spike protein receptorbinding domain (RBD) interacts more efficiently with the hACE2, allowing for better adaptation to infection in humans (Pacheco et al., 2020a; Baric, 2020).

Several attempts have been made to find treatment for COVID-19, yet almost all have failed or failed to achieve satisfactory results, placing even greater hope in possible new vaccines against COVID-19 (Pacheco et al., 2020a). Before the current pandemic, there was not even a standardization of treatments for coronavirus infections, now it is noticeable the need to increase the demand for production and dimensioning of therapies and vaccines, in order to guarantee the survival of the world population and future generations (Wu et al., 2020).

Currently, there are 237 candidate vaccines being developed by laboratories around the world. In the clinical phase it corresponds to a total of 64, being 15 based on nucleic acid (RNA / DNA) platform, carrying a nucleotide sequence encoding the protein of interest (Who, 2020; Ye et al., 2020). Vaccines based on DNA / RNA platforms are also called third generation vaccines and, until now, there were no such vaccines approved for human use (Campos et al., 2020).

The processing and manufacture of DNA and RNA-based vaccines offer advantages because they do not require cultures or fermentation processes, which are time-consuming and expensive, compared to other traditional vaccines that require these steps (Mufamadi, 2020). Some of the systems that are being further explored and used in the development of vaccines based on DNA / RNA are: liposomes, lipid nanoparticles (LNP), with electrophysiological methods, such as electroporation (Ye et al., 2020).

Two RNA vaccines have already completed the final results and achieved more than $90 \%$ effectiveness. These vaccines are from Pfizer-BioNTech, first approved in the United Kingdom, and Moderna/NIH, first approved in the United States, both already being administered to the general population (Ledford, 2020; Pacheco et al., 2020b; Mahase, 2020a).

Due to the new technology used, there is a certain insecurity in the general population if this type of vaccine that uses the genetic material, would be able to integrate into the human genome and cause changes such as, for example, silencing tumor suppressor genes or activating oncogenes.

Here we bring a brief explanation to elucidate this theme that has been questioned a lot by many people of the nonscientific community, and even scientific, so that there is no confusion and dissemination of false information about DNA / RNA vaccines. 


\section{Methodology}

The textual production of this study was developed based on the scientific literature in PubMed, Scielo, and Google Scholar databases. According to the indexes of the various databases, search terms were used: "vaccines for COVID-19", “COVID-19”, "DNA vaccines”, "RNA vaccines”, without any language restrictions.

\section{Do DNA Vaccines Integrate Into the Genome?}

There are currently eight DNA-based candidates vaccines in the clinical phase against COVID-19 (Who, 2020) (Table 1). Some studies have analyzed the possibility of integrating DNA from vaccines into the human genome, a factor that could cause the silencing of tumor suppressor genes or the activation of oncogenes (Wang et al., 2004). However, experiments have already proven that this occurrence in mice is about 1000 copies/ $\mu \mathrm{g}$ DNA, an integration frequency below the spontaneous rate of gene-inactivating mutations (Wang et al., 2004).

However, vectors modified in order to increase immunogenicity may increase the chances of integration into the human genome, but there is no report to date on this either in preclinical or clinical tests (Fig. 1). Therefore, the evidence only reinforces the lack of proof that COVID-19 DNA vaccines could be integrated into the human genome, causing changes in oncogenes or tumor suppressor genes (Kutzler; Weiner, 2008; Naik; Peden, 2020).

Table 1. Landscape of candidate vaccines in clinical phase based on DNA. (on January 2021).

\begin{tabular}{|c|c|c|c|}
\hline Vaccine & Developers & Platform & Phase \\
\hline $\begin{array}{c}\text { INO- } \\
4800+\text { electroporation }\end{array}$ & $\begin{array}{c}\text { Inovio Pharmaceuticals + } \\
\text { International Vaccine } \\
\text { Institute + Advaccine } \\
\text { (Suzhou) } \\
\text { Biopharmaceutical Co., } \\
\text { Ltd }\end{array}$ & $\begin{array}{l}\text { DNA plasmid encoding S } \\
\text { protein delivered by } \\
\text { electroporation }\end{array}$ & $\begin{array}{c}\text { Phase 1 } \\
\frac{\text { NCT04336410 }}{\text { ChiCTR2000038152 }} \\
\text { Phase 1/2 } \\
\frac{\text { NCT04447781 }}{\text { Phase 2 }} \\
\frac{\text { ChiCTR2000040146 }}{\text { Phase 2/3 }} \\
\text { NCT04642638 }\end{array}$ \\
\hline AG0301-COVID19 & $\begin{array}{c}\text { AnGes + Takara Bio + } \\
\text { Osaka University }\end{array}$ & Plasmid DNA & $\begin{array}{c}\text { Phase 1/2 } \\
\frac{\text { NCT04463472 }}{\text { NCT04527081 }} \\
\frac{\mathrm{j} \text { RCT2051200085 }}{\text { Phase 2/3 }} \\
\text { NCT04655625 }\end{array}$ \\
\hline nCov vaccine & Zydus Cadila & Plasmid DNA & $\begin{array}{c}\text { Phase 1/2 } \\
\frac{\text { CTRI/2020/07/026352 }}{\text { Phase 3 }} \\
\text { CTRI/2020/07/026352 }\end{array}$ \\
\hline GX-19 & Genexine Consortium & DNA based vaccine & $\begin{array}{c}\text { Phase 1/2 } \\
\text { NCT04445389 } \\
\end{array}$ \\
\hline Covigenix VAX-001 & $\begin{array}{c}\text { Entos Pharmaceuticals } \\
\text { Inc. }\end{array}$ & DNA based vaccine & $\begin{array}{c}\text { Phase 1 } \\
\text { NCT04591184 } \\
\end{array}$ \\
\hline CORVax & $\begin{array}{c}\text { Providence Health \& } \\
\text { Services }\end{array}$ & DNA based vaccine & $\begin{array}{c}\text { Phase 1 } \\
\text { NCT04627675 }\end{array}$ \\
\hline BacTRL-Spike & Symvivo Corporation & $\begin{array}{l}\text { Genetically modified } \\
\text { probiotic bacteria } \\
\text { with aplasmid DNA }\end{array}$ & $\begin{array}{c}\text { Phase 1 } \\
\text { NCT04334980 } \\
\end{array}$ \\
\hline GLS-5310 & $\begin{array}{l}\text { GeneOne Life Science, } \\
\text { Inc. }\end{array}$ & DNA based vaccine & $\begin{array}{c}\text { Phase 1/2 } \\
\text { NCT04673149 } \\
\end{array}$ \\
\hline
\end{tabular}

Fonte: Who (2020). 
Figure 1. DNA vaccines can integrate into the genome at a lower rate than spontaneous mutations. RNA vaccines are not able to integrate into the genome.

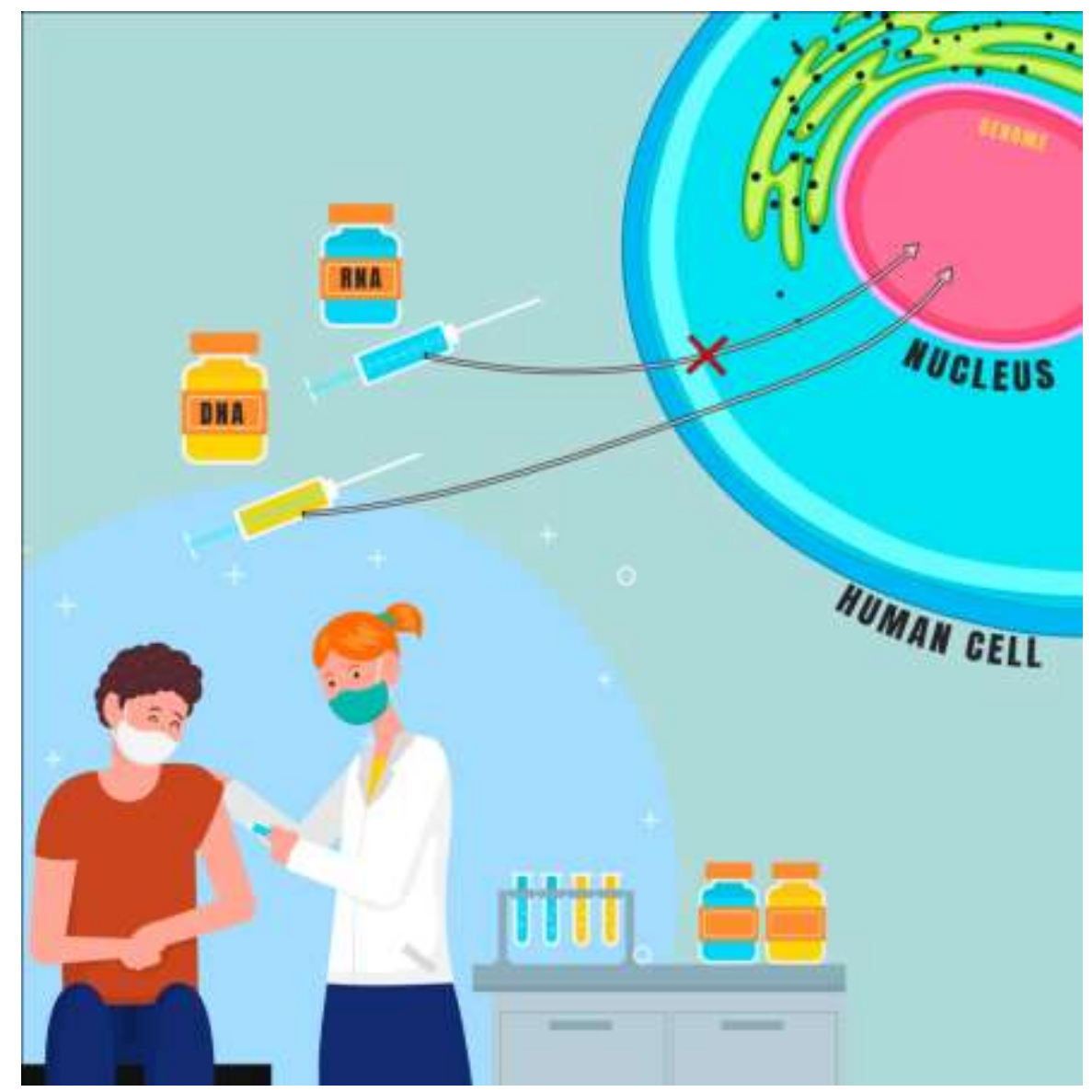

Source: Authors (2020).

\section{Do RNA Vaccines Integrate into the Genome?}

With the advent of advantageous DNA and RNA vaccines, vaccine production time has been reduced dramatically. All it takes is just the antigen gene to make the vaccine (13). There are currently seven RNA-based candidates vaccines in the clinical phase (Who, 2020) (Table 2). Although it still does not have approved DNA vaccines, there are two RNA vaccines approved against COVID-19. Pfizer-BioNTech and Moderna-NIH vaccines work in a similar way (Pacheco et al., 2020b, Mahase, 2020b). But both consist of lipid nanoparticles that encase RNA and encode modified form of the SARS-CoV-2 spike protein to trigger immune response when translated into ribosomes.

The two vaccines differ in the lipid nanoparticles that encapsulate RNA (Ledford, 2020). Whilst there is an infinite concern that DNA vaccines will integrate into the genome, using an RNA vaccine this problem is solved, since RNA does not enter the nucleus where the cell's human genome resides (Figure 1) (Ledford, 2020, Naik; Peden, 2020; Mahase, 2020b; Liu, 2019; Ulmer et al., 2012; Fuller; Berglund, 2020). In addition, there is a great possibility for other products using RNA technology to save thousands of people suffering from other diseases beyond COVID-19 (Fuller \& Berglund, 2020). 
Table 2. Landscape of candidate vaccines in clinical phase based on RNA. (On January 2021).

\begin{tabular}{|c|c|c|c|}
\hline Vaccine & Developers & Platform & Phase \\
\hline mRNA -1273 & $\begin{array}{l}\text { Moderna and National } \\
\text { Institute of Allergy and } \\
\text { Infectious Diseases } \\
\text { (NIAID) }\end{array}$ & $\begin{array}{l}\text { LNP (lipid nanoparticles) } \\
\text {-encapsulated mRNA } \\
\text { vaccine enconding S } \\
\text { protein }\end{array}$ & $\begin{array}{c}\text { Phase 1 } \\
\text { NCT04283461 } \\
\text { Phase 2 } \\
\frac{\text { NCT0 } 4405076}{\text { Phase 2/3 }} \\
\frac{\text { NCT04649151 }}{\text { Phase 3 }} \\
\text { NCT04470427 }\end{array}$ \\
\hline $\begin{array}{c}\text { BNT162 (3 LNP- } \\
\text { mRNAs) }\end{array}$ & $\begin{array}{l}\text { Pfizer/BioNTech and } \\
\text { Fosun Pharma }\end{array}$ & $\begin{array}{c}\text { LNP-encapsulated } \\
\text { mRNA }\end{array}$ & $\begin{array}{c}\text { Phase 1 } \\
\frac{\frac{\text { NCT04523571 }}{\text { ChiCTR2000034825 }}}{\text { Phase 1/2 }} \\
\frac{2020-001038-36}{\frac{\text { NCT04588480 }}{\text { NCT04380701 }}} \\
\frac{\frac{\text { NCT04537949 }}{\text { EUCTR2020-003267-26- }}}{\underline{\text { DE }}} \\
\begin{array}{c}\text { Phase 2 } \\
\text { NCT04649021 } \\
\text { Phase 3 }\end{array} \\
\text { NCT04368728 }\end{array}$ \\
\hline CVnCoV Vaccine & Curevac AG & RNA based vaccine & $\begin{array}{c}\text { Phase 1 } \\
\text { NCT04449276 } \\
\text { Phase 2 } \\
\frac{\text { NCT04515147 }}{\text { PER-054-20 }} \frac{\text { Phase 2/3 }}{\text { NCT04652102 }} \\
\frac{\text { Phase 3 }}{\text { NCT04674189 }} \\
\end{array}$ \\
\hline ARCT-021 & Arcturus Therapeutics & RNA based vaccine & $\begin{array}{c}\text { Phase 1/2 } \\
\text { NCT04480957 } \\
\text { Phase 2 } \\
\text { NCT04668339 } \\
\end{array}$ \\
\hline LNP-nCoVsaRNA & Imperial College London & $\begin{array}{l}\text { LNP encapsulated self- } \\
\text { amplifying RNA } \\
\text { (saRNA) }\end{array}$ & $\begin{array}{c}\text { Phase 1 } \\
\text { ISRCTN17072692 }\end{array}$ \\
\hline $\begin{array}{c}\text { SARS-CoV-2 mRNA } \\
\text { vaccine (ARCoV) }\end{array}$ & $\begin{array}{c}\text { Academy of Military } \\
\text { Science (AMS), Walvax } \\
\text { Biotechnology and } \\
\text { Suzhou Abogen } \\
\text { Biosciences }\end{array}$ & RNA based vaccine & $\begin{array}{c}\text { Phase 1 } \\
\text { ChiCTR2000034112 } \\
\text { ChiCTR2000039212 } \\
\end{array}$ \\
\hline $\begin{array}{c}\text { ChulaCov19 mRNA } \\
\text { vaccine }\end{array}$ & $\begin{array}{c}\text { Chulalongkorn } \\
\text { University }\end{array}$ & $\begin{array}{l}\text { LNP-encapsulated } \\
\text { mRNA }\end{array}$ & $\begin{array}{c}\text { Phase 1 } \\
\text { NCT04566276 }\end{array}$ \\
\hline
\end{tabular}

Fonte: Who (2020).

\section{Final Considerations}

There are no reports of DNA vaccines that have integrated into the host cell genome by silencing tumor suppressor genes or activating oncogenes, there is an infinite possibility that this will occur and it is less than spontaneous mutation. Using RNA in vaccines, the possibility of integrating genetic material into the genome is excluded, further strengthening the safety of these products. There are two RNA vaccines approved against COVID-19 and there is no possibility to integrate into the human genome.

It's evident that knowledge and understanding about the disease and the causative virus, COVID-19 and SARSCoV-2 respectively, are increasingly being consolidated among researchers, government officials and society. However, confusion and the spread of false information represent a danger to all of us. Therefore, studies developed, such as presented 
here, are pertinent to clarify for society, including for the enrichment of the scientific community's knowledge about vaccines based on nucleic acid and the peculiarities involved, as well as the update on those that are already being distributed globally.

We know it's still too early to assess whether the vaccines being made available will be able to minimize or eradicate the current pandemic. So, probably, our next studies may be related to this approach.

\section{Acknowledgements}

We thank the Department of Genetics and Morphology, Institute of Biological Sciences, University of Brasilia (GEM-IB-UnB) for their kind support in providing resources and infrastructure for the study. This work did not receive any specific support, but we would like to thank the funding agencies: the Brazilian National Council for Technological and Scientific Development (CNPq), Coordinating Agency for Advanced Training of Graduate Personnel (CAPES), Foundation for Research Support of the Federal District (FAPDF) an the Dean of Research and Post-Graduation of the University of Brasilia (DPP-UnB).

\section{Funding}

This research did not receive any specific grant from funding agencies in the public, commercial, or not-for-profit sectors.

\section{Conflict on interest}

None.

\section{References}

Baric, R. S. (2020). Emergence of a Highly Fit SARS-CoV-2 Variant. New England Journal of Medicine. 10.1056/NEJMcibr2032888.

Campos, E. V. R., Pereira, A. E. S., de Oliveira, J. L., et al. (2020). How can nanotechnology help to combat COVID-19? Opportunities and urgent need. Journal of Nanobiotechnology. 18(1):1-23. https://doi.org/10.1186/s12951-020-00685-4.

Fuller, D. H., \& Berglund, P. (2020). Amplifying RNA vaccine development. New England Journal of Medicine. $382(25): 2469-2471.10 .1056$ / NEJMcibr2009737.

Koirala, A., Jin Joo, Y., Khatami, A., Chiu, C., \& Britton, P. N. (2020). Vaccines for COVID-19: the current state of play. Pediatric Respiratory Reviews. 10.1016 / j.prrv.2020.06.010.

Kutzler, M. A., \& Weiner, D. B. (2008). DNA vaccines: ready for prime time? Nature Reviews Genetics. 2008; (9)10:776-788. 10.1038/nrg2432.

Ledford, H. (2020). Moderna COVID vaccine becomes second to get US authorization: Two RNA vaccines will be useful as US infections surge, but the speedy authorizations complicate clinical trials. Nature News. <https://www.nature.com/articles/d41586-020-03593-7>.

Liu, M. A. (2019). A Comparison of Plasmid DNA and mRNA as Vaccine Technologies. Vaccines. 2019; 7(2), 37. https://doi.org/10.3390/vaccines7020037.

Mahase, E. (2020). Covid-19: What do we know about the late stage vaccine candidates? British Medical Journal Publishing Group. 371:m4576. https://doi.org/10.1136/bmj.m4576.

Mahase, E. (2020b). Covid-19: UK approves Pfizer and BioNTech vaccine with rollout due to start next week. British Medical Journal Publishing Group.

Mufamadi, M. S. (2020). Nanotechnology shows promise for next-generation vaccines in the fight against COVID-19. Material Matters. 45 (12): 981-982. $10.1557 /$ mrs. 2020.307 .

Naik, R., \& Peden, K. (2020). Regulatory Considerations on the Development of mRNA Vaccines. In: Current Topics in Microbiology and Immunology. Springer, Berlim, Heidelberg. https://doi.org/10.1007/82_2020_220.

Pacheco, T. J. A., Silva, F. M., Souza, D. G., Silva, V. C. M., \& Faria, R. S. (2020a). Coronavirus disease 2019 (COVID-19): Updated evidence of comparative overview, diagnosis and treatments. Revista Cereus. 12(3):228-243. 10.18605/2175-7275/cereus.v12n3p228-243.

Pacheco, T. J. A., Silva, V. C. M., \& Souza, D. G. (2020b). Nano COVID-19 Vaccines: the firsts RNA lipid nanoparticle vaccines being approved from history - Review. Research, Society and Development. 2020b; 9(12), e20191211123. 10.33448/rsd-v9i12.11123.

Ulmer, J. B., Mason, P. W., Geall, A., Mandl, C. W. (2012). RNA-based vaccines. Vaccine. 30(30), 4414-4418. 10.1016/ j.vaccine.2012.04.060.

Who. World Health Organization. (2020). Draft landscape of COVID-19 candidate vaccines. <https://www.who.int/publications/m/item/draft-landscape-ofcovid-19-candidate-vaccines>. 
Wu, D., Koganti, R., Lambe, U. P., Yadavalli, T., Nandi, S. S., \& Shukla, D. (2020). Vaccines and Therapies in Development for SARS-CoV-2 Infections. J. Clin. Med. 2020, 9(6), 1885. https://doi.org/10.3390/jcm9061885.

Wang, Z., Troilo, P. J., Wang, X., Griffiths, I. I. T. G., Pacchione, S. J., Barnum, A. B., et al. (2004). Detection of integration of plasmid DNA into host genomic DNA following intramuscular injection and electroporation. Gene Ther. 11: 711-721. https://doi.org/10.1038/sj.gt.3302213.

Ye, T., Zhong. Z., García-Sastre, A., Schotsaert, M., \& Geest, B. G. D. (2020). Current Status of COVID-19 (Pre) Clinical Vaccine Development. Angew. $\quad C$ hem. Int. Ed. 59, 18885- 1 8897. International Edition: doi.org/10.1002/anie.202008319. German Edition: doi.org/10.1002/ange.202008319. 